\title{
PENGARUH ALIH FUNGSI KAWASAN MANGROVE PADA SIFAT SEDIMEN DAN KEMAMPUAN PENYIMPANAN KARBON
}

\section{THE IMPACT OF MANGROVES CONVERSION ON SEDIMENT PROPERTIES AND CAPACITY TO STORE CARBON}

\author{
Terry Louise Kepel, Restu Nur Af Ati, Yusmiana Puspitaningsih Rahayu \& Novi Susetyo Adi \\ Pusat Riset Kelautan, Badan Riset dan Sumberdaya Manusia Kelautan dan Perikanan, \\ Kementerian Kelautan dan Perikanan Jl. Pasir Putih I, Ancol Timur-Jakarta Utara \\ e-mail : kepel@kkp.go.id
}

Diterima tanggal: 07 Februari 2018 ; diterima setelah perbaikan: 30 Agustus 2018 ; Disetujui tanggal: 04 Desember 2018 DOI: http://dx.doi.org/10.15578/jkn.v13i3.6620

\begin{abstract}
ABSTRAK
Ekosistem mangrove memiliki kemampuan untuk menyerap dan menyimpan karbon. Beberapa penelitian memperlihatkan bahwa penyimpanan karbon terbesar di ekosistem ini ada di sedimen. Namun demikian, kapasitas penyimpanan ini akan menurun karena deforestrasi dan konversi lahan. Tujuan penelitian ini adalah menganalisa dampak alih fungsi lahan mangrove terhadap sifat sedimen serta kemampuannya dalam menyimpan karbon dengan membandingkan dua tipe mangrove yang dikategorikan sebagai mangrove alami dan degradasi/terkonversi. Penelitian dilakukan di empat lokasi yaitu di Kabupaten Berau - Kalimantan Timur dan Karimunjawa-Jawa Tengah yang mewakili daerah alami serta, Kabupaten Pati - Jawa Tengah dan Kabupaten Indramayu - Jawa Barat yang mewakili mangrove yang pernah mengalami alih fungsi lahan dan telah direhabilitasi. Sedimen diambil minimal sampai pada kedalaman satu meter dengan menggunakan soil auger. Sebanyak empat sampel diambil pada setiap core sediment pada interval kedalaman 0-15, 15-30, 30-50 dan 50-100 cm. Hasil menunjukkan bahwa mangrove yang pernah mengalami alih fungsi lahan memiliki nilai prosentasi C (\%), densitas $\mathrm{C}\left(\mathrm{mg} \mathrm{cm}^{-3}\right)$ dan simpanan karbon $\left(\mathrm{MgCha}^{-1}\right)$ yang lebih rendah dibandingkan dengan lokasi yang alami. Kisaran nilai prosentasi karbon, densitas dan simpanan karbon pada daerah rehabilitasi berturut-turut adalah sebesar 1,11 - 2,25\%,0,01 - 0,02 $\mathrm{mg} \mathrm{cm}^{-3}$ dan 94,92-265,26 $\mathrm{Mgha}^{-1}$, sementara untuk wilayah alami pada kisaran 12,54 - 17,14\%, 0,07 - 0,09 $\mathrm{mg} \mathrm{cm}^{-3}$ dan 427,54 - 606,92 $\mathrm{Mgha}^{-1}$. Hasil penelitian ini menunjukkan bahwa alih fungsi lahan mangrove menurunkan kemampuan penyimpanan karbon ekosistem.
\end{abstract}

Kata kunci: Konversi mangrove, sedimen, simpanan karbon, penyerap karbon, densitas karbon.

\section{ABSTRACT}

Mangrove ecosystem can sequester and store carbon. Some studies show that significant amount of carbon storage in this ecosystem are found in the sediment. However, the capacity of mangrove sediment to store carbon will decline due to deforestation and land conversion. The purpose of this study is to analyze the impact of mangrove conversion on its sediment characteristics and capacity to store carbon by comparing two different mangrove characteristics categorized as natural and degraded/converted mangroves. The research was conducted at four sites, namely Berau District - East Kalimantan and Karimunjawa - Central Java representing natural mangrove areas and Pati - Central Java and Indramayu - West Java districts categorized in this study as degraded / converted mangroves. Sediment samples were taken at least up to one meter deep by using soil auger. A total of four samples were taken on each sediment core in depth interval of 0-15, 15-30, 30-50 and 50-100 cm. The result shows that degraded/converted mangroves tend to have lower concentration of $C(\%), C$ density (mg $\left.\mathrm{cm}^{-3}\right)$ and carbon storage $\left(\mathrm{MgCha}^{-1}\right)$ compared to those of the natural mangrove sites. The result implies that mangrove conversion decrease the carbon storage capacity of this ecosystems.

Keywords: Mangrove conversion, sediment, carbon storage, carbon sequester, carbon density. 


\section{PENDAHULUAN}

Sedimen memainkan peran penting di ekosistem pesisir. Selain sebagai media tumbuh, sedimen juga menjadi tempat akumulasi dan penyimpanan berbagai komponen termasuk karbon. Kemampuan sedimen ekosistem pesisir menyimpan karbon dihubungkan dengan kapasitas mitigasi perubahan iklim. Sedimen menyimpan lebih dari 50\% karbon yang ada di dalam ekosistem pesisir (Donato et al., 2011; Phang et al., 2015; Murdiyarso et al., 2015). Hal ini menunjukkan pentingnya sedimen di ekosistem pesisir dalam memerangkap karbon.

Ekosistem mangrove adalah salah satu ekosistem pesisir yang menerima tekanan antropogenik yang besar. Alih fungsi lahan mangrove menjadi lahan budidaya ataupun untuk kepentingan lainnya menunjukkan tren yang makin besar dari tahun ke tahun (FAO 2005; FAO 2007). Di pantai Utara Jawa, eksploitasi dan konversi mangrove menjadi tambak sudah dimulai sejak tahun 1800-an (Van Der Kaars \& Van Den Bergh, 2004; Ilman et al., 2016).

Alih fungsi lahan mangrove akan menurunkan jumlah simpanan karbon di sedimen. Contoh emisi akibat konversi mangrove menjadi tambak di Dominika adalah sebesar 2,244-3,799 $\mathrm{Mg} \quad \mathrm{CO}_{2 \mathrm{e}}$ /ha $\quad\left(\mathrm{CO}_{2}\right.$ equivalents) (Kauffman et al., 2014). Lebih lanjut, karbon yang tersimpan di daerah yang terkonversi tersebut hanya sebesar 4\% dari total karbon ekosistem. Atwood et al. (2017) menghitung potensi emisi $\mathrm{CO}_{2}$ akibat kehilangan mangrove secara global adalah sebesar 7.0 $\mathrm{Tg} \mathrm{CO}_{2 \mathrm{e}} \mathrm{yr}^{-1}$.

Tujuan penelitian ini adalah untuk menganalisa dampak alih fungsi lahan mangrove terhadap kandungan fisik dan kimia sedimen serta kemampuannya dalam menyimpan karbon sebagai mitigasi perubahan iklim di Indonesia dengan studi kasus di Berau, Pati dan Indramayu. Untuk mencapai tujuan ini, dilakukan analisa pada ekosistem mangrove yang pernah terdegradasi karena alih fungsi lahan kemudian dibandingkan dengan ekosistem mangrove yang masih alami.

\section{BAHAN DAN METODE}

\section{Lokasi Penelitian}

Penelitian dilakukan di empat lokasi yaitu di BidukBiduk, Kabupaten Berau - Kalimantan Timur, Karimunjawa dan Kabupaten Pati di Jawa Tengah serta
Kabupaten Indramayu - Jawa Barat. Keempat lokasi tersebut mewakili ekosistem mangrove yang alami (Kabupaten Berau dan Karimunjawa) dan mangrove rehabilitasi karena pernah mengalami alih fungsi (Kabupaten Pati dan Indramayu) (Gambar 1).

Biduk-biduk merupakan salah satu kecamatan pesisir yang berada di bagian selatan kabupaten Berau dan terletak di sepanjang pantai timur provinsi Kalimantan Utara. Kondisi perairan pantai kecamatan Bidukbiduk berbatasan langsung dengan Laut Sulawesi dan Selat Makasar. Mangrove di Kabupaten Berau dapat ditemukan mulai dari bagian utara di Tanjung Batu, Delta Berau, sampai ke selatan di Biduk-biduk. Penelitian dilakukan di kawasan mangrove pesisir Tanjung Batu hingga Tanjung Bohei dan sepanjang pesisir Delta Berau.

Lokasi penelitian di Karimunjawa adalah di Pulau Kemujan yang merupakan wilayah taman nasional laut Karimunjawa. Daerah ini terletak di perairan Laut Jawa yang berjarak kurang lebih 45 mil laut dari kota Jepara termasuk dalam wilayah administratif Kecamatan Karimunjawa, Kabupaten Dati II Jepara.

Kabupaten Pati memiliki garis pantai sepanjang 60 km yang melintasi 7 kecamatan yaitu Dukuhseti, Tayu, Margoyoso, Trangkil, Wedarijaksa, Juwana dan Batangan. Kementerian Kelautan dan Perikanan (KKP) telah melakukan rehabilitasi lahan mangrove di Kabupaten ini. Total luasan yang direhabilitasi sebesar 27,15 ha yang mencakup kecamatan Wedarijaksa, Batangan dan Trangkil.

Wilayah Kabupaten Indramayu memiliki panjang garis pantai $\pm 114,1 \mathrm{~km}$ yang membentang sepanjang pantai utara antara Cirebon sampai dengan Subang. Ekosistem mangrove dapat dijumpai pada 4 Kecamatan yaitu Kecamatan Cantigi, Kandanghaur, Losarang dan Sindang. Hasil penelitian Marcello (2012) menunjukkan bahwa secara keseluruhan luasan mangrove sebesar 3.700,16 ha di Kabupaten Indramayu terus berkurang sejak tahun 1989 sampai 2010 menjadi 2.156,08 ha. Ekosistem mangrove di Cantigi terdegradasi sekitar 45\%, Kandanghaur 97\%, Losarang 30\% dan Sindang 27\%. Marcello (2012) juga melaporkan bahwa Kecamatan Cantigi dan Losarang memiliki hutan mangrove yang cukup luas.

\section{Pengambilan Sampel Sedimen}

Jumlah titik pengambilan berkisar antara 8 - 21 lokasi. Jumlah titik ditentukan berdasarkan luas kawasan 

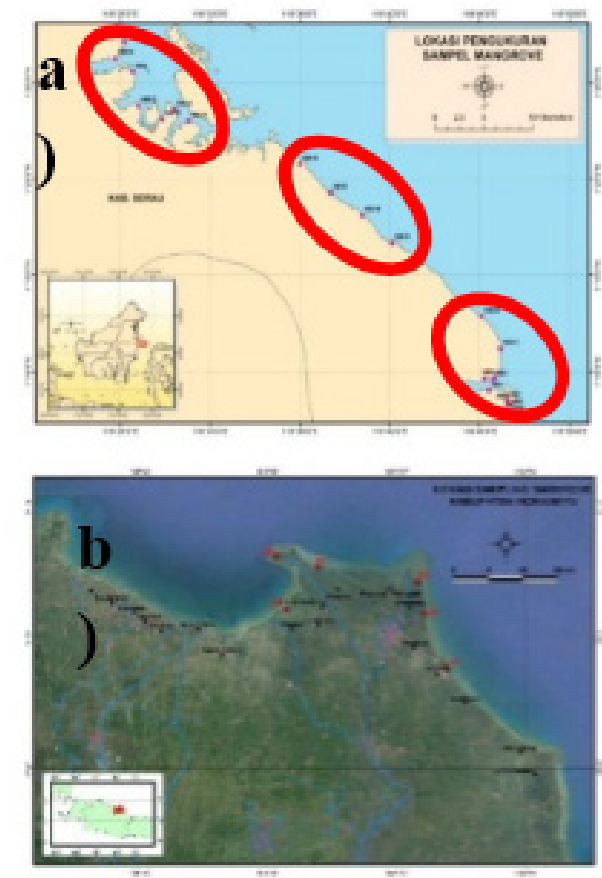
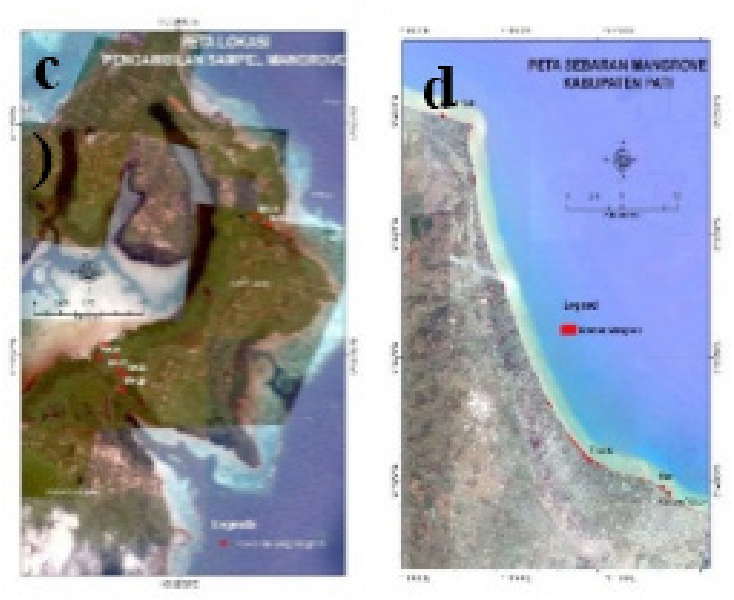

Gambar 1. Lokasi penelitian a). Biduk-biduk; b). Indramayu; c). Karimun; dan d). Pati.

Figure 1. Study Sites a). Biduk-Biduk; b). Indramayu; c). Karimun; dan d). Pati.

mangrove. Hal ini diharapkan dapat merepresentasikan luas kawasan tersebut.

Pengambilan sampel dilakukan di setiap lokasi penelitian dengan menggunakan soil auger yang ditancapkan ke dalam sedimen dengan minimal kedalaman sebesar satu meter. Pengambilan sedimen sampai kedalaman dua meter hanya dilakukan di Kabupaten Pati. Pada setiap core sedimen, diambil empat sampel sedimen yang mewakili kedalaman 0-15, 15-30, 30-50 dan 50-100 cm. Pada kedalaman di atas satu meter, sampel diambil pada kedalaman 100-130, 130-150 dan 150-200 cm. Sampel sedimen dibungkus dengan kertas aluminium dan ditandai. Selanjutnya sampel ditimbang kering dan dianalisa kandungan kimia di laboratorium.

\section{Analisis Sampel}

Sampel sedimen dianalisa diLaboratoriumBioteknologi Tanah, Departemen Tanah dan Sumberdaya Lahan IPB. Hasil analisa meliputi parameter bulk density (BD), konsentrasi karbon dan nitrogen (C, N \%), perbandingan nilai konsentrasi $\mathrm{C} / \mathrm{N}$. Parameter $\mathrm{C}$ dan $\mathrm{N}$ dianalisa dengan menggunakan alat CHNS Analyzer. Bulk density (BD) atau kerapatan massa sedimen adalah berat kering sedimen pada suatu volume tertentu. Perhitungan bulk density berdasarkan rumus :
Bulk density $=\frac{\text { berat kering sampel }(\mathrm{g})}{\text { volume sampel }\left(\mathrm{cm}^{3}\right)}$

\section{Analisis Statistik}

Anova dua arah digunakan untuk melihat perbedaan setiap parameter antar lokasi dengan tingkat kepercayaan 0,05 . Untuk melihat secara deskriptif kemiripan relatif antar lokasi berdasarkan parameter yang ada (konsetrasi $\mathrm{C}$, konsentrasi $\mathrm{N}$, bulk density dan densitas C) maka dilakukan analisis biplot dengan menggunakan open source software PAST 3.20.

\section{HASIL DAN PEMBAHASAN}

\section{Bulk Density (BD)}

Nilai BD tergantung pada jenis sedimen dan juga terkait dengan pertumbuhan akar pohon. Nilai BD yang besar biasanya pada sedimen pasir $\left(1,3-1,7 \mathrm{~g} / \mathrm{cm}^{3}\right)$ , sedangkan untuk lanau dan lempung biasanya lebih rendah $\left(1,1-1,6 \mathrm{~g} / \mathrm{cm}^{3}\right)$ (Anonim, 2016). Nilai BD yang lebih rendah $\left(0,5 \mathrm{~g} / \mathrm{cm}^{3}\right)$ biasanya pada sedimen yang mengandung material organik yang tinggi. Berbagai kegiatan di sedimen seperti pengolahan tanah dan budidaya dapat mengubah BD secara cepat.

Rerata bulk density sedimen berdasarkan kedalaman di 


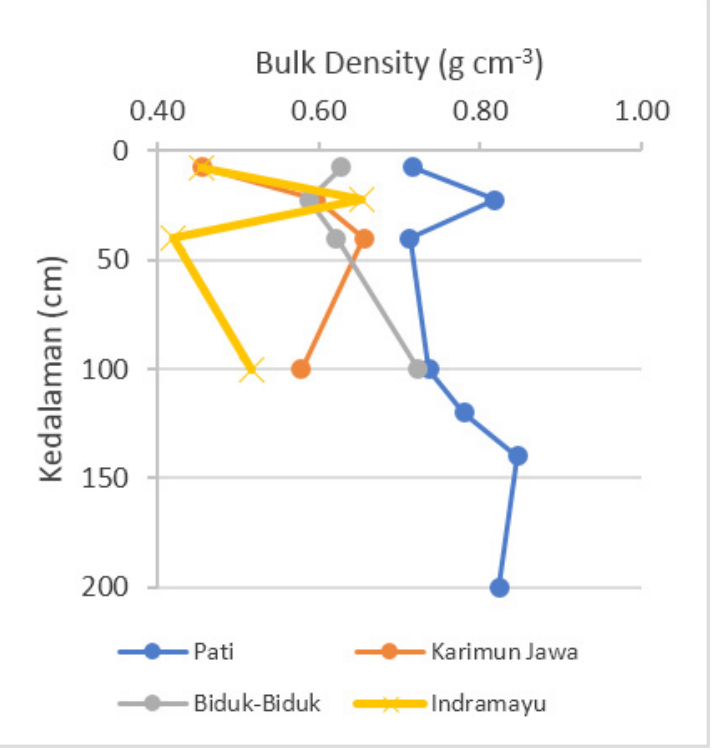

Gambar 2. Rerata Bulk Density $\left(\mathrm{g} \mathrm{cm}^{-3}\right)$ sedimen. Figure 2. Mean Bulk Density $\left(\mathrm{g} \mathrm{cm}^{-3}\right)$ of sediment.

lokasi penelitian ditampilkan di gambar 2. Rerata BD

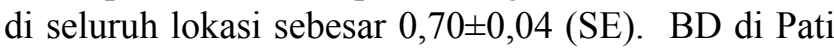
paling besar diikuti oleh Biduk-Biduk, Karimun Jawa dan Indramayu, dengan nilai berturut-turut sebesar $0,77 \pm 0,02$ (kisaran $\left.0,71-0,85 \mathrm{~g} / \mathrm{m}^{3}\right) ; 0,64 \pm 0,03(0,59$ $\left.0,72 \mathrm{~g} / \mathrm{m}^{3}\right) ; 0,57 \pm 0,04\left(0,46-0,66 \mathrm{~g} / \mathrm{m}^{3}\right)$ dan $0,51 \pm 0,05$ $\left(0,46-0,66 \mathrm{~g} / \mathrm{m}^{3}\right)$. Nilai BD terendah ditemukan di Indramayupada kedalaman 30-50 cm sedangkan yang tertinggi pada kedalaman $130-150 \mathrm{~cm}$ di Pati.

Hasil analisa statistik menunjukkan bahwa ada perbedaan nilai $\mathrm{BD}$ antar lokasi dengan nilai signifikansi sebesar 0,035. Perbedaan BD terjadi antar lokasi Karimujawa dan Biduk-Biduk terhadap Pati dan Indramayu.

Dibandingkan dengan sedimen permukaan, nilai BD di sedimen bagian dalam relatif lebih tinggi. Namun demikian, hasil statistik menunjukkan tidak adanya perbedaan signifikan antar kedalaman di semua lokasi. Kecenderungan meningkatnya BD seiring meningkatnya kedalaman juga ditunjukkan oleh hasil penelitian Lunstrum \& Chen (2014) pada beberapa tingkatan umur ekosistem mangrove di China serta Murdiyarso et al. (2015) pada mangrove di beberapa tempat di Indonesia. Hal yang sama juga teridentifikasi di ekosistem mangrove pesisir laut merah Mesir (Eid et al., 2015). Hal ini kemungkinan terjadi karena efek kompaksi (pemadatan) yang semakin besar di sedimen bagian dalam. Penyebab lain yang mungkin adalah akumulasi serasah yang tinggi di permukaan sedimen (Eid et al., 2015).

\section{Konsentrasi Nitrogen (N), Karbon (C) dan Rasio CN}

Ekosistem mangrove adalah salah satu ekosistem pesisir yang memiliki produktivitas yang tinggi. Menurut Alongi (2014), nilai produktifitas primer netto (Net Primary Production/NPP) rata-rata sebesar $11,1 \mathrm{MgC} \mathrm{ha}^{-1}$ thn $^{-1}$ dan produksi netto ekosistem (Net Ecosystem Production/NEP) sebesar $90 \mathrm{TgC}$ thn $^{-1}$. Produktifitas mangrove sangat terkait dengan berbagai faktor termasuk unsur-unsur kimiawi yang merupakan sumber nutrisi (Alongi et al., 2005).

Nitrogen $(\mathrm{N})$ salah satu unsur kimia yang sangat penting di alam karena dapat mengontrol produktivitas biologi. Nitrogen yang biasanya dalam bentuk ammonium serta fosfor berperan penting dalam pertumbuhan mangrove (Feller et al., 1999; Feller et al., 2003; Reef et al., 2010; Verhoeven et al., 2014).

Rerata konsentrasi N (\%) di semua lokasi penelitian sebesar $0,53 \pm 0,03$ dengan nilai tertinggi di Karimunjawa dan terendah di Pati. Secara umum, Karimunjawa memiliki nilai $\mathrm{N}$ yang lebih tinggi diikuti oleh Indramayu, Biduk-Biduk dan Pati (Gambar 3). Rerata konsentrasi N (\%) di Karimunjawa sebesar $0,66 \pm 0,07 \quad(0,62-0,72)$, Indramayu $0,60 \pm 0,01 \quad(0,59$ $0,62)$, Biduk-Biduk $0,56 \pm 0,09(0,52-0,60)$ dan Pati $0,41 \pm 0,04(0,37-0,44)$.

Tingginya konsentrasi nitrogen di Karimunjawa mungkin terjadi karena beberapa hal. Pertama karena masukan nitrogen yang berasal dari serasah. Biasanya serasah mengandung $\mathrm{N}$ yang sangat kecil $(<1 \%)$. Hal ini dapat dilihat dari rasio $\mathrm{C}: \mathrm{N}$ yang tinggi (Cannicci et al., 2008). Namun demikian, saat terjadi proses dekomposisi nilai nitrogen menjadi tinggi akibat fiksasi $\mathrm{N}$ oleh mikroorgnisme (Reef et al., 2010). Mandal et al. (2012) mengidentifikasi sumber nitrogen di sedimen ekosistem mangrove Sundarban, India berasal dari detritus alga, organisme infauna serta mikroflora. Kedua, adanya transfer dari ekosistem pesisir yang berada di depan mangrove yaitu lamun yang difasilitasi oleh arus pasang surut. Pertukaran bahan organik dan inorganik antara ekosistem pesisir merupakan suatu hal yang mungkin terjadi (Carr et al., 2010). Ketiga, nitrogen yang berasal dari daratan akan menambah akumulasi nitrogen di dalam sedimen. Salah satu sumber nitrogen dari daratan adalah buangan dari tambak udang (Trott et al., 2004).

Selain sebagai sumber nitrogen, serasah mangrove juga merupakan sumber karbon di ekosistem mangrove dan 


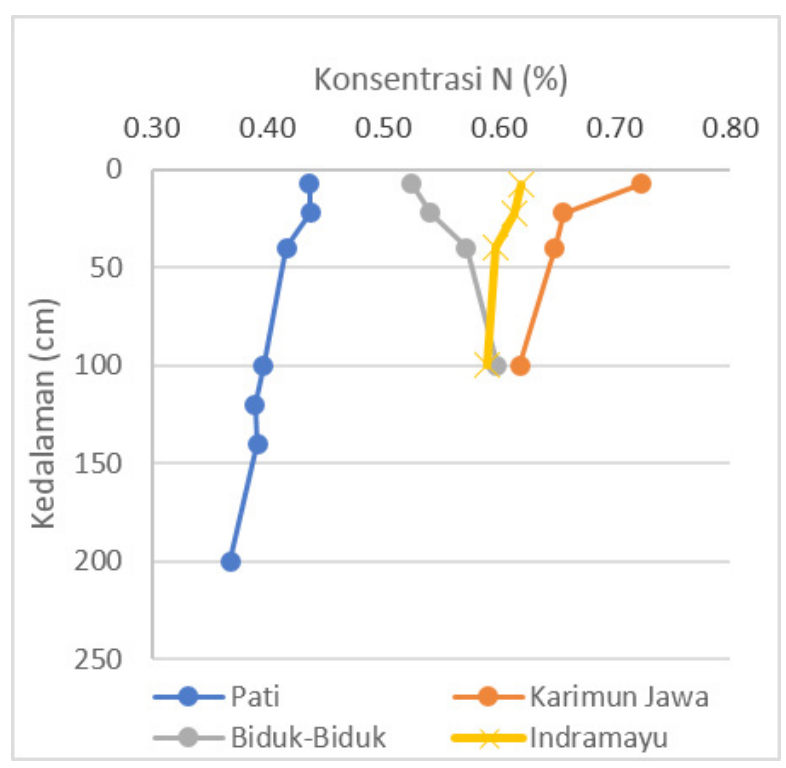

Gambar 3. Rerata Konsentrasi N (\%) berdasarkan kedalaman di lokasi penelitian.

Figure 3. Profile of Nitrogen mean concentration (\%) at study site.

sekitarnya. Sekitar $50 \%$ produksi serasah mangrove tertranspor ke lingkungan pesisir sekitarnya melalui presipitasi dan pasang surut (Adame \& Lovelock, 2011; Alongi, 2014). Bahkan menurut Chen et al. (2017), mangrove adalah sumber utama organik karbon ke ekosistem lamun yang ada di sekitarnya.

Menurut Alongi (2014), sebagian besar karbon yang di sedimen ekosistem mangrove berasal dari mangrove $(58 \%)$ dan sisanya dari daratan atau laut. Laju penenggelaman (burial rate) karbon di sedimen mangrove mencapai $24 \mathrm{TgC} \mathrm{y}^{-1}$ secara rata-rata global.

Konsentrasi karbon (C\%) di lokasi penelitian berkisar antara 1,75 -2,25\% di Pati; 1,11 - 1,72 \% di Indramayu; 12,54-15,16\% di Biduk-Biduk dan 13,71-17,14 \% di Karimunjawa (Gambar 4). Secara rerata konsentrasi karbon di Karimunjawa lebih tinggi dari tiga lokasi yang lain, berturut-turut Karimunjawa $(15,85 \pm 1,95 \%)$, Biduk-Biduk $(13,91 \pm 1,46 \%)$, Pati $(1,96 \pm 0,18 \%)$ dan Indramayu $(1,52 \pm 0,24 \%)$.

Konsentrasi karbon di Pati dan Indramayu lebih rendah dibandingkan dengan data konsentrasi karbon di Cilacap yang memiliki konsentrasi terendah hasil penelitian Murdiyarso et al. (2015) di delapan ekosistem mangrove di Indonesia.Namun nilai konsentrasi karbon dari dua tempat ini sebanding dengan nilai tengah global (global median) yaitu sebesar 2,2 \% (Kristensen et al., 2008 ) atau dengan mangrove di delta sungai Zambesi di Mozambik (Stringer et al., 2016).

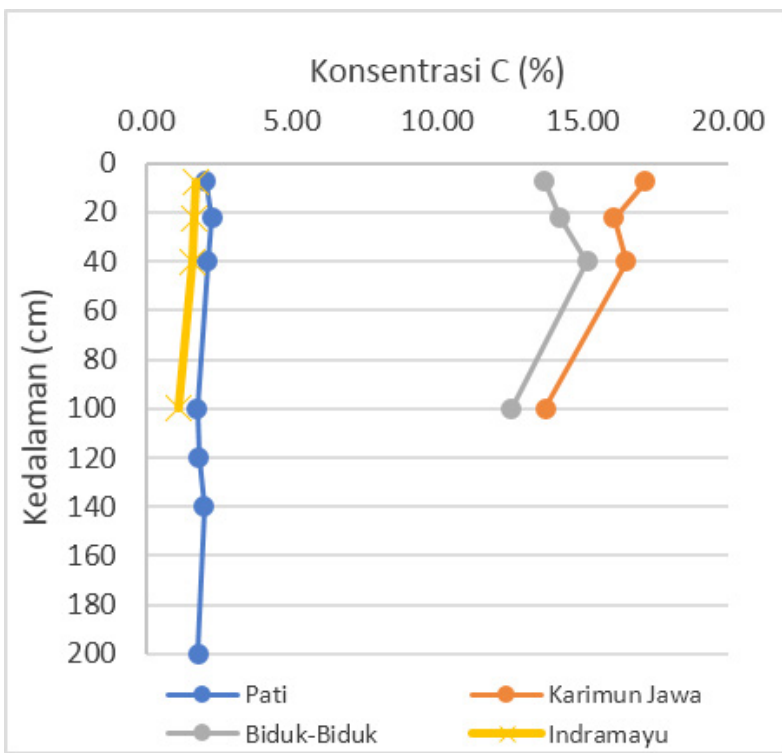

Gambar 4. Rerata Konsentrasi C (\%) berdasarkan kedalaman di lokasi penelitian.

Figure 4. Profile of Carbon mean concentration (\%) at study site.

Rendahnya konsentrasi karbon di Pati dapat dihubungkan dengan rusaknya ekosistem mangrove di kabupaten ini selama bertahun-tahun. Menurut Dinas Kelautan dan Perikanan Kabupaten Pati, luas ekosistem mangrove di Pati tersisa hanya sekitar 10\% pada tahun 2008 dibandingkan dengan luasan awal tahun 1971 (Anonim, 2008). Pati menjadi salah satu kabupaten di Jawa Tengah yang memiliki tingkat kerusakan mangrove terparah selain kabupaten Kendal dan Rembang. Selanjutnya, sejak tahun 2002 telah dilakukan upaya rehabilitasi oleh Pemda Kabupaten Pati dan Departemen Kehutanan. Pada tahun 2012, Kementerian Kelautan dan Perikanan (KKP) melalui dana dekonsentrasi telah mengadakan rehabilitasi di Kabupaten Pati seluas 27,15 ha dengan menanam kurang lebih 500.000 batang mangrove.

Sama halnya dengan Pati, ekosistem mangrove di Indramayu juga pernah mengalami alih fungsi menjadi areal tambak. Penurunan luasan ekosistem mangrove sekitar $80 \%$ selama 20 tahun dari 8000 ha menjadi 1600 ha (Rusdianti, 2012). Kegiatan rehabilitasi mangrove di Indramayu khususnya di Desa Karongsong dimulai pada tahun 1998 atas inisiatif NGO Wetland Indonesia yang melibatkan penduduk lokal (Prayudha dkk, 2014). Kegiatan rehabilitasi mangrove yang dilakukan oleh KKP dimulai sejak tahun 2000. Sampai dengan tahun 2015, telah direhabilitasi sekitar 132,25 ha mangrove. Di semua lokasi, konsentrasi karbon terlihat menurun seiring bertambahnya kedalaman. Profil konsentrasi 


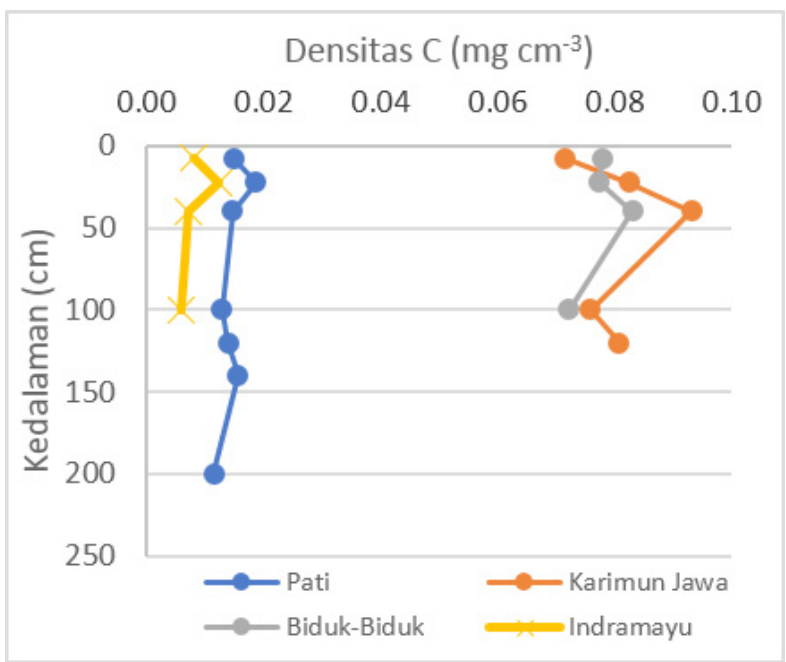

Gambar 5. Rerata Densitas C (mg cm$\left.{ }^{-3}\right)$ berdasarkan kedalaman di lokasi penelitian.

Figure 5. Profile of Carbon mean density (\%) at study site

karbon seperti ini juga sama dengan yang diteliti oleh Donatoet et al. (2011) pada 25 lokasi di Indo-Pasifik termasuk Indonesia.

Sama seperti konsentrasi karbon, densitas karbon (mg/ $\mathrm{cm}^{3}$ ) pada keempat lokasi penelitian menunjukkan bahwa densitas karbon di Pati dan Indramayu lebih rendah dibandingkan Karimun Jawa dan Biduk-Biduk (Gambar 5). Densitas karbon setiap lokasi berkisar antara 0,01-0,02 di Pati; 0,01 di Indramayu; 0,07-0,08 di Biduk-Biduk dan 0,07-0,09 di Karimun Jawa.

\section{Penyimpanan Karbon di Sedimen}

Simpanan karbon di sedimen lokasi penelitian ditampilkan pada gambar 6. Simpanan karbon per hektar berturut-turut adalah sebesar $606,92 \pm 59,74 \mathrm{MgC}^{-1} \mathrm{di}$ Karimunjawa, 427,84 $\pm 51,53 \mathrm{MgC} \mathrm{ha}^{-1}$ di Biduk-Biduk, $265,26 \pm 9,08 \mathrm{MgC}^{-1}$ di Pati dan 94,92 $\pm 21,82 \mathrm{MgC}$ ha $^{-1}$ di Indramayu.Besar simpanan karbon yang ada di keempat lokasi ini masih lebih rendah dibandingkan dengan rata-rata karbon sedimen di delapan lokasi di Indonesia (Sembilang, Cilacap, Kubu Raya, Tanjung Puting, Bunaken, Teminabuan, Bintuni, Timika) yang sebesar $849 \pm 323 \mathrm{MgC} \mathrm{ha}^{-1}$ (Murdiyarso et al., 2015). Hasil analisa data simpanan karbon sedimen oleh Alongi et al. (2015) di 37 ekosistem mangrove yang tersebar dari Sumatra sampai Papua adalah rerata sebesar $761.3 \pm 73.6 \mathrm{MgC} \mathrm{ha}^{-1}$.

Tren simpanan karbon per hektar ini sama dengan tren konsentrasi kandungan karbon dimana Karimunjawa dan Biduk-Biduk lebih tinggi dibandingkan dengan Pati dan Indramayu.Rendahnya simpanan karbon di Pati dan Indramayu kemungkinan karena alih fungsi lahan yang menurunkan tutupan vegetasi dan berakibat pada terkikisnya lapisan organik bagian atas. Menurut Lal (2014), erosi pada lapisan tanah atas akan menghilangkan kandungan karbon organik, menurunkan kedalaman lapisan tanah atas (topsoil), kesuburan tanah dan kapasitas penyimpanan air. Hal ini mengindikasikan bahwa daerah mangrove yang mengalami kerusakan dan atau konversi lahan, selain mengalami kehilangan karbon dari biomas pohon juga dari stok karbon yang tersimpan di sedimen. Kalkulasi besarnya karbon yang terlepas akibat konversi mangrove menjadi tambak di Indonesia dalam tiga dekade sejak tahun 1980-an adalah sebesar 0.07-0.21 $\mathrm{PgCO}_{2}$ e per tahun (Murdiyarso et al., 2015). Kehilangan simpanan karbon dalam sedimen juga bisa mencapai kedalaman lebih dari 1 meter (Kauffman et al., 2014).

Salah satu cara untuk meningkatkan kembali simpanan karbon di sedimen adalah melalui upaya rehabilitasi atau penanaman mangrove. Hasil penelitian Nguyen \& Mar (2007) pada penanaman mangrove di daerah Giaolac Provinsi Giaothuy Vietnam telah meningkatkan simpanan karbon. Namun demikian, masih rendahnya simpanan karbon pada lahan rehabilitasi mangrove di Kabupaten Pati dan Indramayu menunjukkan bahwa pada kondisi tertentu, proses penambahan vegetasi tidak akan langsung berpengaruh secara signifikan kepada penambahan karbon di sedimen. Peningkatan

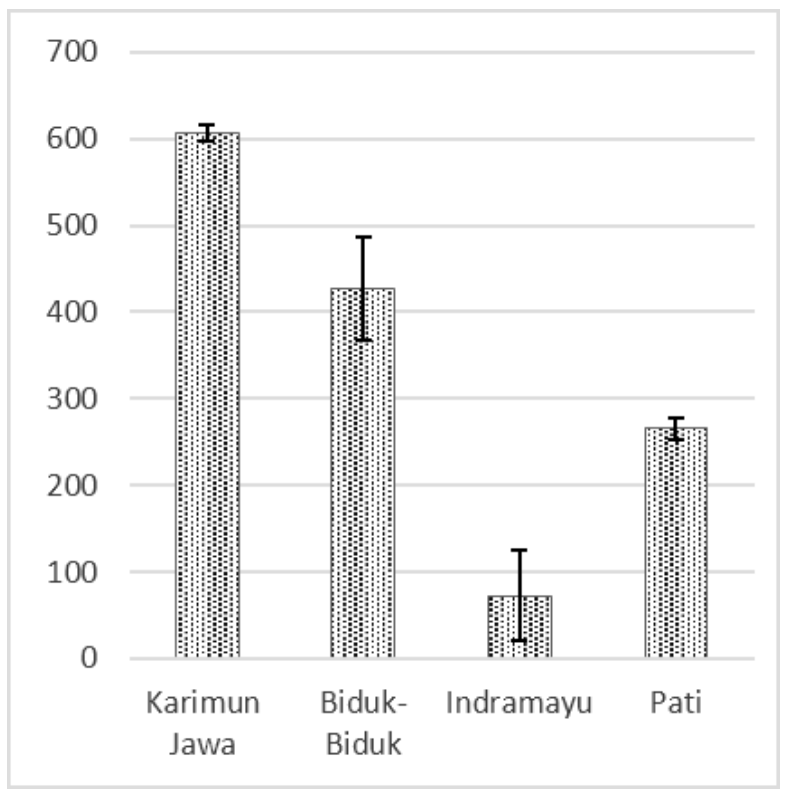

Gambar 6. Simpanan Karbon di lokasi penelitian $\left(\mathrm{MgC} \mathrm{ha}{ }^{-1} \pm \mathrm{SE}\right)$.

Figure 6. Carbon storage at study sites $\left(\mathrm{MgCh} \mathrm{a}^{-1} \pm \mathrm{SE}\right)$. 


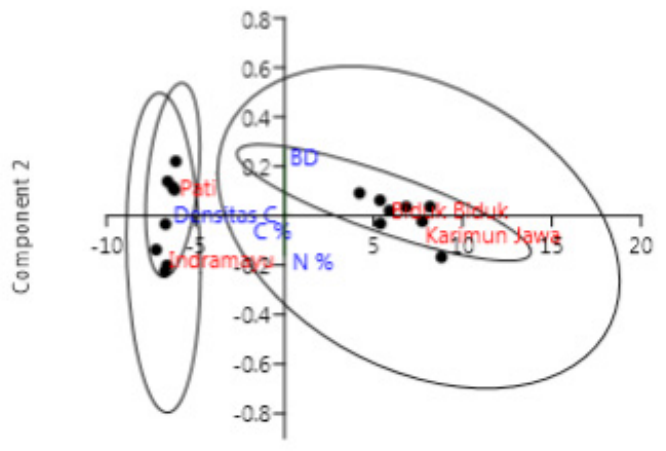

Component 1

Gambar 6. Simpanan Karbon di lokasi penelitian ( $\mathrm{MgC}$ ha- $1 \pm \mathrm{SE})$.

Figure 6. Carbon store at study sites $(\mathrm{MgCh}-1 \pm S E)$.

simpanan karbon di ekosistem mangrove berkorelasi positif dengan peningkatan usia pohon mangrove (Hieu et al., 2017).

\section{Karakteristik Lokasi}

Berdasarkan karakteristik nilai bulk density, konsentrasi C-N, serta densitas $\mathrm{C}$, secara deskriptif dapat digambarkan bahwa lokasi penelitian dapat dibagi dalam 2 kelompok yaitu Pati, Indramayu dan Karimun Jawa - Biduk- Biduk (Gambar 6). Nilai BD dan $\mathrm{N}$ pada keempat lokasi berada pada kisaran yang sama namun tidak demikian dengan $\mathrm{C}$, densitas $\mathrm{C}$ dan simpanan karbon.

Pati dan Indramayu yang merupakan daerah rehabilitasi memiliki nilai prosentasi karbon (C\%), densitas karbon $\left(\mathrm{mg} \mathrm{cm}^{-3}\right)$ dan simpanan karbon yang lebih rendah dibandingkan dengan Biduk-biduk dan Karimun Jawa. Kisaran nilai prosentasi karbon, densitas dan simpanan karbon pada daerah rehabilitasi berturut-turut adalah sebesar $1,11-2,25 \%, 0,01-0,02 \mathrm{mg} \mathrm{cm}^{-3}$ dan 94,92265,26 $\mathrm{Mgha}^{-1}$, sementara untuk wilayah alami pada kisaran 12,54 - 17,14\%, 0,07 - 0,09 $\mathrm{mg} \mathrm{cm}^{-3}$ dan 427,54 - 606,92 $\mathrm{Mgha}^{-1}$.

\section{KESIMPULAN DAN SARAN}

\section{Kesimpulan}

Adanya perbedaan karakteristik fisik dan kimia pada daerah yang relatif alami yaitu Karimunjawa dan
Biduk-Biduk dibandingkan dengan Pati dan Indramayu yang merupakan daerah rehabilitasi. Dibutuhkan waktu untuk meningkatkan simpanan karbon pada lahan yang pernh mengalami alih fungsi. Apabila kondisi ekosistem mangrove di Pati dapat ditingkatkan baik dari sisi luasan maupun sisi ekologis maka akan meningkatkan kapasitasnya dalam menyimpan karbon.

\section{Saran}

Perlu adanya monitoring pada daerah rehabilitasi untuk melihat seberapa efektif upaya rehabilitasi dalam meningkatkan simpanan karbon di sedimen.

\section{UCAPAN TERIMA KASIH}

Tulisan ini merupakan hasil analisa kegiatan di 2018 dari sebagian data hasil kegiatan penelitian Karbon Biru tahun 2016 di Pusat Penelitian dan Pengembangan Sumberdaya Laut dan Pesisir (P3SDLP), Badan Penelitian dan Pengembangan Kelautan dan Perikanan, Kementerian Kelautan dan Perikanan. Penelitian ini didanai oleh DIPA TA 2018 Pusat Riset Kelautan, Badan Riset dan Sumberdaya Manusia Kelautan dan Perikanan

\section{DAFTAR PUSTAKA}

Adame M. F. \& Lovelock, C. E. (2011). Carbon and nutrient exchange of mangrove forests with the coastal ocean. Hydrobiologia 663: 23-50.

Alongi, D.M., Ramanathan, A. L., Kannan, L., Tirendi, F., Trott, L. A. \& Prasad, M. B. K. (2005). Influence of human-induced disturbance on benthic microbial metabolism in the Pichavaram mangroves, Vellar-Coleroon estuarine complex, India. Mar Biol147:1033-44.

Alongi, D. M. (2012). Carbon sequestration in mangrove forests. Carbon Management, 3, 313-322.

Alongi, D. M. (2014). Carbon cycling and storage in mangrove forest. Annu. Rev. Mar. Sci 6: 195-219.

Alongi, D. M., Murdiyarso, D., Fourqurean, J. W., Kauffman, J. B., Hutahaean, A., Crooks, S., Lovelock, C. E., Howard, J., Herr, D., Fortes, M., Pidgeon, E. \& Wagey, T. (2015). Indonesia's blue carbon : a globally significant and vulnerable sink for seagrass and mangrove carbon. Wetland Ecology Management, Vol. 23, Issue 3. DOI: 10.1007/s11273-015-9446-y.

Anonim. (2008). Mangrove di Pati tinggal 10 persen. http:// megapolitan.kompas.com/read/2008/12/31/0011159/ Mangrove.di.Pati.Tinggal.10.Persen. Diunduh pada Desember 2016.

Anonim. (2016). Fact Sheets Bulk Density - Measurement. http://soilquality.org.au/factsheets/bulk-densitymeasurement. Diunduh pada Desember 2016. 
Atwood, T. B., Connolly, R. M., Almahasheer, H., Carnell, P. E., Duarte, C. M., Lewis, C. J. E., Irigoien, X., Kelleway, J. J., Lavery, P. S., Macreadie, P. I., Serrano, O., Sanders, C. J., Santos, I., Steven, A. D. L. \& Catherine, E. L. (2017). Global patterns in mangrove soil carbon stocks and losses. Nat Clim Change. Doi: 10.1038/NCLIMATE3326

Boer, W. F. (2000). Biomass dynamics of seagrasses and the role of mangrove and seagrass vegetation as different nutrient sources for an intertidal ecosystem. Aquatic Botany 66: 225-239.

Cannicci, S., Burrows, D., Fratini, S., Smith, T. J., Offenberg, J. \& Dahdouh-Guebas, F. (2008). Faunal impact on vegetation structure and ecosystem function in mangrove forests: a review. Aquatic Botany 89.

Carr, J., D'Odorico, P., McGlathery, K., \& Wiberg, P. (2010). Stability and bistability of seagrass ecosystems in shallow coastal lagoon: Role of feedbacks with sediment resuspension and light attenuation. $J$ Geophys Res. G03011. 115:1-14. oi:10.1029/2009JG001103.

Chen, G., Azkab, M. H., Chmura, G. L., Chen, S., Sastrosuwondo, P., Ma, Z., Dharmawan, I. W. E. \& Chen, B. (2017). Mangroves as a major source of soil carbon storage in adjacent seagrass meadows. Scientific Reports, 7, 42406. http://doi.org/10.1038/ srep42406

Damayanti, H. O. (2015). Implementasi Perda Nomor 4 tahun 2003 terhadap pengelolaan mangrove di Kabupaten Pati. Neptunus Jurnal Kelautan, Vol. 19, No.2.

Dislautkan Kab. Pati. (2013). Kondisi Tanaman Mangrove. Laporan Kegiatan. Pati.

Donato, D. C., Kauffman, J. B., Murdiyarso, D., Kurnianto, S., Stidham, M. \& Kanninen, M. (2011). Mangrove among the most carbon-rich forest in the tropics. Nature Geoscience, Vol. 4. DOI: 10.1038/NGEO1123.

Eid, E. M. \& Shaltout, K. H. (2015). Distribution of soil organic carbon in the mangrove Avicennia marina (Forssk.) Vierh. Along the Egyptian Red Sea Coast. Regional Studies in Marine Science. http://dx.doi. org/10.1016/j.rsma.2015.05.006

FAO. (2005). Global Forest Resources Assessment 2005. Thematic Study on Mangrove, Indonesia Country Profile. FAO Forestry Dept. 12 pp.

FAO. (2005). The World's Mangrove 1980 - 2005. A Thematic study prepared in the framework of the Global Forest Resources Assessment 2005. FAO Forestry Paper 153. $77 \mathrm{pp}$.

Feller I.C., Whingham, D. F., O’Neill, J. P. \& McKee, K. L. (1999). Effects of nutrient enrichment on withinstand cycling in a mangrove forest. Ecology, Vol. 80,No.7: 2193-2205 pp.

Feller, I. C., Whingham, D. F., McKee, K. L. \& Lovelock, C. E. (2003). Nitrogen limitation growth and nutrient dynamics in a disturbed mangrove forest, Indian River Lagoon, Florida. Oecologia 134: 405-414. DOI 10.1007/s00442-002-1117-z
Giesen, W. (1993). Indonesian Mangroves: An Update on Remaining Area and Main Management Issues. International Seminar on Coastal Zone Mangement of Small Island Ecosystem, Ambon,7-10 April 1993

Haryadi J., Basukriadi, A. \& Muhadiono. (2013). The study on mangrove litters as a source of nutrients for Blanakan mangrove pond, Subang, West Java. Indonesian Aquaculture Journal Vol. 8, No.1. Hal : 55-64.

Hieu, P. V., Dung, L. V., Tue, N. T. \& Omori, K. (2017). Will restored mangroveforests enhance sediment organic carbon and ecosystem carbon storage. Regional Studies in Marine Science. http://dx.doi.org/10.1016/j. rsma.2017.05.003

Ilman, M., Darguscha, P., Dartc, P. \& Onrizal. (2016). A historical analysis of the drivers of loss and degradation of Indonesia's mangroves. Land Use Policy 54: 448-459 p. http://dx.doi.org/10.1016/j. landusepol.2016.03.010 0264-8377/

Kauffman, J. B., Heider, C., Norfolk, J. \& Payton, F. (2014). Carbon stocks of intact mangroves and carbon emissions arising from their conversion in the Dominican Republic. Ecological Applications, 24(3), pp. 518-527.

Kristensen, E., Bouillon, S., Dittmar, T. \& Marchand, C. (2008). Organic carbon dynamics in mangrove ecosystems: areview. Aquat Bot 89:201-219

Lal, R. (2014). Soil conservation and ecosystem services. International Soil and Water Conservation Research, Vol. 2, No. 3, 2014, pp. 36-47.

Lunstrum, A. \& Chen, L. (2014). Soil carbon stocks and accumulation in young mangrove forests. Soil Biology and biochemistry 75: 223-232.

Mandal, S., Ray, S. \& Ghosh, P. B. (2012). Comparative study of mangrove litter nitrogen cycling to the adjacent estuary through modelling in pristine and reclaimed islands of Sundarban mangrove ecosystem, India. Environmental Sciences 8: 340 - 362.

Marcello, H. (2011). Perubahan Mangrove di Wilayah Pesisir Indramayu. Fakultas Matematika dan Ilmu Pengetahuan Alam Departemen Geografi. Skripsi. Universitas Indonesia.

Murdiyarso, D., Purbopusito, J., Kauffman, J. B., Warren, M. W., Sasmito, S. D., Donato, D. C., Manuri, S., Krisnawati, H., Taberima, S. \& Kurnianto, S. (2015). The potentials of Indonesian mangrove forests for global change mitigation. Nat Clim Change. Doi:10.1038/nclimate2734

Nguyen, T. H. H. \& Mai, S. T. (2007). Effects of mangrove plantation on carbon and nitrogen stock accumulated in soil. Tap Chi Sinh Hoc, Journal of Biology. Vol. 29, No. 3. DOI: 10.15625/0866-7160/v29n3.5388.

Valerie, X. H. Phang, V. X. H., Chou, L. M. \& Friess, D. A. (2015). Ecosystem carbon stocks across a tropical intertidal habitat mosaic of mangrove forest, seagrassmeadow, mudflat and sandbar. EARTH SURFACE PROCESSES AND LANDFORMS, Earth Surf. Process. Landforms 40: 1387-1400. DOI: 
10.1002/esp.3745.

Prayudha, E. D., Sulardiono, B. \& Hendrarto, B. (2014). Strategi kelompok pantai Lestari dalam pengembangan kegiatan rehabilitasi mangrove di Desa Karangsong Kabupaten Indramayu. Diponegoro Journal of Maquares, Vol. 3 No.3. Hal : 80-87.

Reef, R., Feller, I. C. \& Lovelock, C. E. (2010). Nutrition on mangroves. Invited Review: Part of An Invited Issue on Tree Nutrition. Tree Physiology 30, 1148-1160. doi:10.1093/treephys/tpq048

Scharler , U. M. (2011). Whole Food-Web Studies: Mangroves. University of KwaZulu-Natal, Durban, South Africa.

Setyawan, A. D., Winarno, K. \& Purnama, P. C. (2003). Ekosistem Mangrove di Jawa: 1. Kondisi Terkini. Biodiversitas Vol. 4, No. 2, Juli 2003, hal. 130-142.

Stringer, C. E., Trettin, C. C. \& Zarnoch, S. J. (2016). Soil properties of mangroves in contrasting geomorphic settings within the Zambezi River Delta, Mozambique. Wetlands Ecol Manage (2016) 24:139-152. DOI 10.1007/s11273-015-9478-3.

Trott, L. A., McKinnona, A. D., Alongi, D. M., Davidson, A. \& Burford, M. A. (2004). Carbon and nitrogen processes in a mangrove creek receiving shrimp farm effluent. Estuarine, Coastal and Shelf Science 59: 197-207.

Verhoeven, J. T. A., Laanbroek, H. J., Rains, M. C., \& Whigham, D. F. (2014). Effects of increased summer flooding on nitrogen dynamics in impounded mangroves. Journal of Environmental Management 139: 217-226pp. http://dx.doi.org/10.1016/j. jenvman.2014.02.035.

Van Der Kaars, S. \& Van Den Bergh, G. D. (2004). Anthropogenic changes in the landscape of westJava (Indonesia) during historic times, inferred froma sediment and pollen record from Teluk Banten. Journal of Quaternary Science 19(3): 229-239. DOI: 10.1002/jqs.804.

University of Waikato. (2010). http://sciencelearn.org. nz/Contexts/The-Ocean-in-Action/Sci-Media/ Interactive/Carbon-cycle. Diiunduh pada Desember 2016. 
